\title{
ENKAPSULASI CAMPURAN MINYAK ATSIRI SEBAGAI PRODUK SEDIAAN AROMATERAPI DENGAN TEKNIK KOASERVASI KOMPLEKS
}

\section{ENCAPSULATION OF THE ESSENTIAL OIL BLENDS AS AN AROMATHERAPY PRODUCT BY COMPLEX COACERVATION}

\author{
Annisa Putri*), Meika Syahbana Rusli, dan Dwi Setyaningsih \\ Program Studi Teknik Industri Pertanian, Fakultas Teknologi Pertanian, IPB University \\ Kampus IPB Dramaga PO Box 220, Bogor 16680, Indonesia \\ Email: annisaputri1606@gmail.com
}

Makalah: Diterima 11 November 2020; Diperbaiki 20 Desember 2020; Disetujui 25 Desember 2020

\begin{abstract}
Essential oils are used as raw materials in the flavors and fragrances industry. Essential oils contain active compounds that are volatile at ambient temperature so that it is unstable to environmental changes. Complex coacervation is one of the techniques used in the encapsulation process to protect the active material. Essential oil blends were encapsulated by gelatin and maltodextrin as wall material and sodium tripolyphosphate as crosslinking agent. The objective of this study was to analyze the effect of the proportion between essential oils, wall material, and crosslinking agents on the yield, loading capacity, and encapsulation efficiency. The results showed that the optimum formulation for microcapsules was the essential oil and wall material ratio 1:2 and crosslinking agent concentration of 3\%, with the yield of $45.18 \%$, loading capacity of $5.37 \%$, and encapsulation efficiency of $92.20 \%$. The microcapsule size obtained was $0.1475 \mu \mathrm{m}$ with polydispersity index of 0.410 .
\end{abstract}

Key words: complex coacervation, encapsulation, essential oil, gelatin, maltodextrin

\section{ABSTRAK}

Minyak atsiri digunakan sebagai bahan baku pada industri perisa dan wewangian. Minyak atsiri memiliki senyawa aktif yang mudah menguap pada suhu ruang sehingga tidak stabil terhadap perubahan lingkungan. Koaservasi kompleks adalah salah satu teknik yang digunakan dalam proses enkapsulasi untuk melindungi senyawa aktif. Campuran minyak atsiri dienkapsulasi menggunakan gelatin dan maltodekstrin sebagai penyalut dan sodium tripolifosfat sebagai crosslinking agent. Tujuan dari penelitian ini adalah menganalisis pengaruh perbandingan antara minyak atsiri, penyalut dan crosslinking agent terhadap tiga parameter yaitu yield, loading capacity, dan efisiensi enkapsulasi. Hasil penelitian menunjukkan bahwa formulasi terbaik adalah mikrokapsul dengan perbandingan minyak atsiri dan penyalut adalah 1:2 dan konsentrasi crosslinking agent $3 \%$, dengan yield $45,18 \%$, loading capacity 5,37\% dan efisiensi enkapsulasi $92,20 \%$. Ukuran mikrokapsul yang didapatkan adalah $0,1475 \mu \mathrm{m}$ dengan indeks polidispersitas 0,410 .

Kata kunci: enkapsulasi, minyak atsiri, gelatin, maltodekstrin, koaservasi kompleks

\section{PENDAHULUAN}

Minyak atsiri mengandung senyawa aromatik yang banyak dimanfaatkan dalam bidang kecantikan, kesehatan dan pangan. Saat ini permintaan produk aromaterapi sangat meningkat di masyarakat sehingga sangat berpotensi untuk dikembangkan. $\mathrm{Hal}$ ini menjadi tantangan bagi industri untuk menghasilkan aromaterapi berkualitas tinggi yang berbasis pada minyak atsiri (non-sintetis) tanpa bahan kimia yang berdampak negatif terhadap kesehatan dan lingkungan.

Beberapa jenis minyak atsiri yang digunakan sebagai aromaterapi adalah lavender, rosemary, akar wangi, sereh dapur, sereh wangi, geranium dan nilam (Ali et al., 2015). Minyak atsiri lavender menjadi salah satu minyak atsiri yang paling digemari untuk aromaterapi karena efek relaksasi dan penghilang stres yang baik. Minyak atsiri sereh dapur dan sereh wangi juga memiliki banyak manfaat, tidak hanya untuk aromaterapi tetapi juga sebagai anti nyamuk dan anti mikroba. Saat ini trend yang banyak diproduksi oleh industri adalah campuran minyak atsiri untuk mendapatkan manfaat aromaterapi yang lebih maksimal dan aroma yang lebih unik. Minyak atsiri memiliki karakteristik yang mudah menguap dan tidak stabil pada suhu ruang sehingga akan mengurangi efektivitas aplikasi produk, oleh karena itu diperlukan alternatif teknologi yang mampu menyelesaikan hal tersebut yaitu enkapsulasi.

Enkapsulasi merupakan teknologi yang efisien secara ekonomi, mudah dilakukan dengan proses yang cukup cepat (Botrel et al., 2015). Enkapsulasi dapat dilakukan dengan beberapa teknik seperti koaservasi kompleks, gelasi ionik, sentrifugasi, liofilisasi, dan spray drying. Koaservasi kompleks disebut juga dengan teknik pemisahan yang melibatkan fase larutan dan fase koloid, dimana pada 
teknik ini material inti dienkapsulasi dengan matriks (Gupta et al., 2016). Teknik koaservasi kompleks memiliki beberapa keunggulan yaitu tidak memerlukan biaya tinggi, tanpa penggunaan pelarut dan cocok diaplikasikan pada senyawa hidrofobik seperti minyak atsiri (Xiao et al., 2013). Teknik ini menghasilkan mikrokapsul dalam bentuk emulsi atau wet microcapsule, sehingga membutuhkan proses pengeringan untuk mendapatkan produk sediaan dalam bentuk bubuk. Proses pengeringan yang digunakan pada penelitian ini adalah spray drying, karena proses ini unggul dari segi waktu dan biaya.

Faktor penting yang mempengaruhi keberhasilan teknik koaservasi kompleks adalah penambahan crosslinking agent yang berfungsi untuk memperkuat ikatan matriks yang terbentuk. Penggunaan crosslinking agent ini akan melindungi senyawa aktif pada matriks terhadap suhu tinggi saat proses pengeringan. Shetta et al. (2018), menggunakan senyawa crosslinking agent yaitu sodium tripolifosfat untuk mengenkapsulasi minyak atsiri peppermint dan teh hijau dengan efisiensi enkapsulasi $82 \%$. Sodium tripolifosfat memiliki sifat yang stabil di dalam emulsi sehingga cocok digunakan sebagai crosslinking agent. Pengembangan penelitian enkapsulasi minyak atsiri menggunakan teknik koaservasi kompleks yang telah dilakukan menunjukkan hasil yang optimal dan mampu meningkatkan mutu dari produk. Hal tersebut dapat dilihat dari hasil penelitian Manaf et al. (2018) yang melakukan enkapsulasi single aroma minyak sitronela menggunakan penyalut gelatin dan gum arab dengan nilai efisiensi enkapsulasi 94\%.

Penelitian ini menggunakan campuran dari minyak atsiri lavender (Lavandula afficinalis syn. $L$. angustifolia), sereh dapur (Cymbopogon citratus) dan sereh wangi (Cymbopogon nardus L. Rendl). Minyak atsiri dienkapsulasi menggunakan gelatin dan maltodekstrin sebagai penyalut dan sodium tripolifosfat sebagai crosslinking agent. Gelatin dan maltodekstrin adalah penyalut yang cocok digunakan pada teknik koaservasi kompleks karena memiliki kemampuan yang sangat baik untuk mengikat molekul, termasuk golongan turunan protein dan polisakarida alami yang ramah lingkungan. Berdasarkan latar belakang tersebut, maka tujuan dari penelitian ini adalah menganalisis pengaruh perbandingan antara minyak atsiri, penyalut dan konsentrasi crosslinking agent terhadap karakteristik mikrokapsul untuk mendapatkan formulasi terbaik.

\section{BAHAN DAN METODE}

\section{Bahan dan Alat}

Bahan yang digunakan adalah minyak atsiri lavender yang berasal dari PT Xoso Essential Oil, minyak atsiri sereh dapur dan sereh wangi yang berasal dari PT Indesso Aroma, gelatin dan maltodekstrin, akuades, tween $80, \mathrm{CH}_{3} \mathrm{COOH}$, sodium tripolifosfat, $\mathrm{NaOH}$. Alat yang digunakan dalam proses koaservasi kompleks adalah adalah magnetic stirrer, homogenizer, indikator $\mathrm{pH}$ dan gelas kimia. Alat yang digunakan dalam proses pengeringan adalah Spray Dryer. Alat yang digunakan untuk mengukur total minyak adalah Soxhlet dan Rotary Vacuum Evaporator. Alat untuk pengukuran mikrokapsul adalah Particle Size Analyzer,

\section{Metode \\ Pembuatan Produk Sediaan Aromaterapi \\ Penentuan Formulasi Bahan Pembentuk Mikrokapsul}

Produk sediaan aromaterapi dibuat dengan perbandingan bahan pembentuk mikrokapsul yang berbeda. Perbandingan bahan pembentuk mikrokapsul terdiri dari dua faktor perlakuan. Faktor pertama adalah perbandingan antara minyak atsiri dan penyalut yaitu A1(2:1), A2(1:1) dan A3(1:2). Faktor kedua adalah penambahan crosslinking agent dengan konsentrasi yang berbeda yaitu E1(2\%) dan E2(3\%).

\section{Persiapan Larutan Bahan Penyalut}

Persiapan larutan bahan penyalut mengacu pada prosedur Manaf et al. (2018) dan Kamala (2010) yang dimodifikasi. Penyalut yang digunakan yaitu gelatin dan maltodekstrin dengan konsentrasi masingmasing 2,5\%. Sebanyak 2,5 g gelatin dilarutkan di dalam $100 \mathrm{~mL}$ air dan dilakukan proses homogenisasi dengan kecepatan $700 \mathrm{rpm}$ pada suhu $50^{\circ} \mathrm{C}$ selama 1 jam hingga terbentuk larutan gelatin. Tahapan yang sama dilakukan untuk larutan maltodekstrin.

\section{Enkapsulasi Campuran Minyak Atsiri}

Enkapsulasi dengan teknik koaservasi kompleks mengacu pada prosedur Manaf et al. (2018) dan Bezerra et al. (2016) yang dimodifikasi. Proses ini terdiri dari dua tahap yaitu (1) pembuatan emulsi minyak atsiri dengan penyalut dan (2) koaservasi kompleks. Tahap pertama adalah pembuatan emulsi dengan menggunakan larutan gelatin dan maltodekstrin. Sebanyak $100 \mathrm{~mL}$ larutan gelatin dicampurkan dengan 5 g campuran minyak atsiri (komposisi lavender, sereh dapur dan sereh wangi berturut-turut adalah 0,75 g, 3,25 g dan 1,0 g) dan tween 80 sebanyak 5,6 g (perbandingan minyak dan surfaktan 1:1,12) (Shetta et al., 2018), kemudian dihomogenisasi dengan kecepatan $700 \mathrm{rpm}$ pada suhu ruang selama 30 menit. Proses selanjutnya ditambahkan $100 \mathrm{~mL}$ larutan maltodekstrin dan dihomogenisasi dengan kecepatan $700 \mathrm{rpm}$ pada suhu ruang selama 30 menit.

Tahap selanjutnya adalah proses koaservasi kompleks. Proses pertama adalah penambahan larutan $\mathrm{CH}_{3} \mathrm{COOH} 10 \%$ sebanyak $\pm 2 \mathrm{~mL}$ ke dalam fase emulsi hingga $\mathrm{pH}$ turun menjadi 4. Emulsi kemudian dihomogenisasi kembali pada kecepatan $700 \mathrm{rpm}$ pada suhu ruang selama 60 menit. Emulsi disimpan pada suhu $\pm 10^{\circ} \mathrm{C}$ selama 30 menit. Proses selanjutnya penambahan $20 \mathrm{~mL}$ larutan sodium 
tripolifosfat sebagai crosslinking agent dan dilakukan homogenisasi kembali selama 60 menit. Penyesuaian $\mathrm{pH}$ dilakukan untuk memperkuat dinding matriks yang terbentuk yaitu dengan penambahan larutan $\mathrm{NaOH} 20 \% \pm 3 \mathrm{~mL}$ ke dalam emulsi hingga $\mathrm{pH}$ mencapai 9. Tahap terakhir dilakukan homogenisasi pada kecepatan $700 \mathrm{rpm}$ pada suhu ruang selama 2 jam. Emulsi didiamkan pada suhu $\pm 10^{\circ} \mathrm{C}$ selama 16 jam untuk mendapatkan kondisi yang stabil sebelum dilakukan pengeringan menggunakan spray dryer.

\section{Karakterisasi Mikrokapsul}

\section{Yield (Burhan et al., 2019)}

Yield adalah perbandingan antara jumlah mikrokapsul yang didapatkan setelah proses pengeringan dengan jumlah bahan pembentuk mikrokapsul meliputi minyak atsiri, penyalut dan crosslinking agent yang dihitung berdasarkan bobot kering (g). Yield dapat dihitung dengan rumus berikut:

$$
\text { Yield }(\%)=\frac{\text { Bobot Mikrokapsul (g) }}{\text { Bahan Pembentuk Mikrokapsul (g) }} \times 100
$$

\section{Loading Capacity (Burhan et al., 2019)}

$$
\text { Loading capacity }(\%)=\frac{\mathrm{Weo}}{\mathrm{Wmp}} \times 100
$$

Dimana Weo adalah berat minyak atsiri yang terenkapsulasi (g) dan Wmp adalah berat sampel mikrokapsul yang didapatkan setelah proses pengeringan $(\mathrm{g})$.

\section{Efisiensi Enkapsulasi}

Perhitungan dilakukan berdasarkan surface oil dan total minyak mikrokapsul. Perhitungan surface oil mengacu pada Yunika (2017) yang dimodifikasi. Sebanyak 2 g sampel ditimbang (a) dan dimasukkan ke dalam labu evaporator yang telah diketahui bobot tetapnya (b). Proses dilanjutkan dengan pencucian sampel dengan $40 \mathrm{~mL}$ heksan selama 2 menit sebanyak 3 kali. Filtrat diuapkan menggunakan rotary vacuum evaporator pada suhu $40^{\circ} \mathrm{C}$ hingga seluruh pelarut menguap. Labu ditimbang untuk mengetahui bobot akhir (c). Surface oil dapat dihitung dengan rumus berikut:

$$
\text { Surface oil }(\%)=\frac{c-b}{a} \times 100
$$

Proses selanjutnya yaitu perhitungan total minyak, sebanyak $10 \mathrm{~g}$ sampel dimasukkan kedalam kertas saring (d), kemudian dimasukkan kedalam rangkaian alat soxhlet yang telah dihubungkan ke labu lemak (yang telah dikeringkan di oven dan diketahui bobotnya). Sampel diekstrak selama 5 jam menggunakan heksan. Sisa heksan kemudian diuapkan di dalam labu evaporator kosong yang telah ditimbang (e) dan proses penguapan dilakukan dengan rotary vacuum evaporator. Labu evaporator kemudian ditimbang (f), diulangi hingga bobotnya konstan sehingga total minyak dihitung dengan rumus:

$$
\begin{aligned}
& \text { Total Minyak }(\%)=\frac{f-e}{d} \times 100 \\
& \operatorname{EE}(\%)=\frac{\text { Total minyak - Surface Oil }}{\text { Total minyak }} \times 100
\end{aligned}
$$

\section{Penentuan Formulasi Terbaik}

Perlakuan terbaik dianalisis menggunakan metode indeks efektivitas (DeGarmo et al., 1984). Metode ini dilakukan dengan pemberian bobot pada masing-masing parameter berdasarkan kepentingan dengan rentang 0-1. Formulasi terbaik didapatkan berdasarkan nilai produk tertinggi. Perhitungan:

$$
\begin{gathered}
\mathrm{BN}=\frac{\text { Bobot perlakuan }}{\text { Total bobot perlakuan }} \\
\mathrm{NE}=\frac{\text { Nilai perlakuan }- \text { Nilai terendah }}{\text { Nilai tertinggi }- \text { Nilai terendah }} \\
\mathrm{NP}=\mathrm{BN} x \mathrm{NE}
\end{gathered}
$$

Keterangan:

$\mathrm{BN}=$ Bobot Nilai;

NE $=$ Nilai Efektivitas;

$\mathrm{NP}=$ Nilai Produk

\section{Ukuran Mikrokapsul}

Ukuran mikrokapsul dari formulasi terbaik akan diukur menggunakan alat Particle Size Analyzer (PSA) Malvern Mastersizer (Malvern Instruments). Analisis dilakukan dengan pengukuran sel tunggal dengan sampel media cair dan metode Dynamic Light Scattering (DLS). Suhu dan durasi pengukuran adalah $25^{\circ} \mathrm{C}$ dan 70 detik.

\section{Analisis Data}

Rancangan pada penelitian ini adalah rancangan acak kelompok (RAK) dengan dua faktor perlakuan dan tiga kali ulangan sehingga didapatkan 18 kombinasi perlakuan. Faktor perlakuan pertama terdiri dari tiga perbandingan minyak atsiri dan penyalut yaitu A1, A2 dan A3. Faktor perlakuan kedua terdiri dari dua konsentrasi crosslinking agent yaitu E1 dan E2. Berdasarkan rancangan yang digunakan maka model linier pada penelitian ini adalah sebagai berikut:

$$
Y i j=\mu+\tau i+\beta j+\varepsilon i j
$$

Yij adalah nilai pengamatan yang diperoleh pada perlakuan ke-i dan kelompok ke-j, $\mu$ adalah nilai rata-rata populasi, $\tau i$ adalah pengaruh dari perlakuan $\mathrm{ke}-\mathrm{i}, \beta \mathrm{j}$ adalah pengaruh dari kelompok ke-j dan $\varepsilon \mathrm{ij}$ adalah pengaruh acak dari perlakuan ke-i dan kelompok ke-j. Data hasil analisis pada penelitian akan diuji secara statistik menggunakan analisis ragam ANOVA dan SPSS. Jika terdapat perbedaan akan dilanjutkan dengan uji Least Significant Differences (LSD) pada tingkat kepercayaan dengan taraf $95 \%$ dan nilai signifikansi $\alpha=5 \%(0,05)$. 


\section{HASIL DAN PEMBAHASAN}

\section{Produk Sediaan Aromaterapi Terenkapsulasi}

Minyak atsiri yang digunakan adalah campuran dari minyak atsiri lavender (Lavandula afficinalis syn. L. angustifolia), sereh dapur (Cymbopogon citratus) dan sereh wangi (Cymbopogon nardus L. Rendl). Aroma ketiga minyak atsiri ini memiliki karakteristik yang berbeda tergantung dari komponen senyawa aromatik terbesar dari masing-masing minyak atsiri. Proses pembuatan mikrokapsul terdiri dari pembuatan emulsi dan pengeringan emulsi menggunakan alat spray dryer. Proses pertama adalah pembuatan emulsi dengan teknik koaservasi kompleks hingga didapatkan wet mikrokapsul. Tahap selanjutnya adalah pengeringan emulsi dengan proses spray drying hingga didapatkan dry mikrokapsul. Produk sediaan aromaterapi terenkapsulasi dapat dilihat pada Gambar 1.

Komponen senyawa aktif penyusun ketiga minyak atsiri ini berbeda-beda. Komponen senyawa terbesar pada minyak atsiri lavender adalah linalyl acetate $39,10 \%$, linalool $29,70 \%$, dan $\alpha$-terpineol $4,35 \%$ (Singh et al., 2015). Komponen senyawa terbesar pada minyak atsiri sereh dapur adalah sitral $34,80 \%$ dan neral 30,72\% (Ali et al., 2017). Komponen senyawa terbesar pada minyak atsiri sereh wangi adalah sitronelal $36,11 \%$, geraniol $20,07 \%$ dan sitronelol 10,82\% (Harianingsih et al., 2017). Selain komponen terbesar dari masing-masing minyak atsiri ini, masih banyak senyawa lain yang teridentifikasi pada pengukuran menggunakan instrumen Gas Chromatography-Mass Spectrometry (GC-MS) namun memiliki persentase yang kecil.

\section{Karakteristik Mikrokapsul}

Minyak atsiri, penyalut dan crosslinking agent yang digunakan pada setiap formulasi memiliki perbandingan yang berbeda sehingga pada penelitian ini dilihat karakteristik dari masing-masing formulasi terhadap parameter yang diukur. Hasil penelitian menunjukkan adanya perbedaan masing-masing formulasi terhadap karakteristik mikrokapsul yang dijelaskan pada Tabel 1.

\section{Yield Mikrokapsul}

Hasil analisis ragam menunjukkan nilai signifikansi yang lebih kecil dari 5\% $(\alpha=0,05)$, sehingga perbandingan minyak atsiri, penyalut dan crosslinking agent memberikan pengaruh yang nyata terhadap nilai yield yang dihasilkan. Hasil perhitungan yield menunjukkan formulasi dengan konsentrasi crosslinking agent 3\% memiliki nilai lebih tinggi dibandingkan formulasi dengan konsentrasi crosslinking agent 2\%. Penggunaan crosslinking agent 3\% mampu meningkatkan nilai yield karena emulsi yang dihasilkan lebih stabil sehingga saat pengeringan menghasilkan mikrokapsul bubuk dengan jumlah yang lebih tinggi.

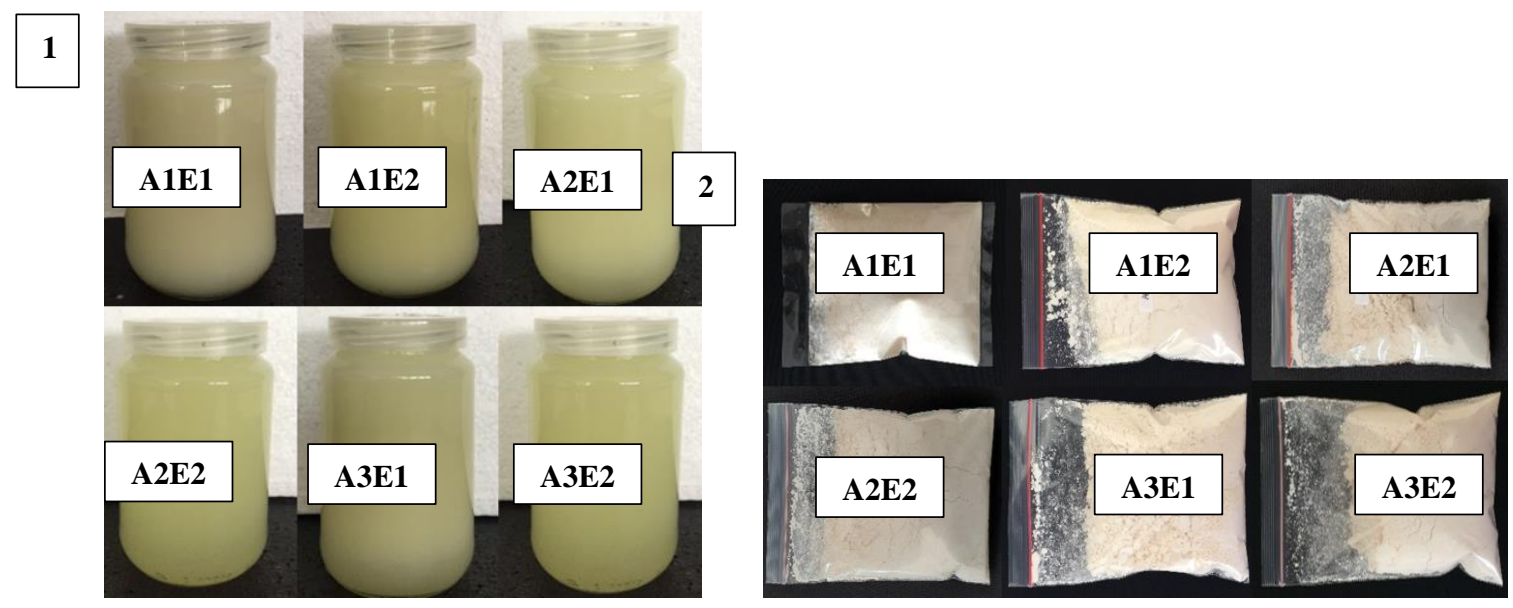

Gambar 1. (1) Wet mikrokapsul dan (2) Dry mikrokapsul

Tabel 1. Hasil analisis minyak atsiri terenkapsulasi dengan perbandingan minyak atsiri, penyalut dan crosslinking agent terhadap tiga parameter

\begin{tabular}{cccccc}
\hline Formulasi & M:P & $\mathbf{C A ~}(\boldsymbol{\%} \mathbf{b} / \mathbf{v})$ & $\mathbf{Y}(\boldsymbol{\%})$ & $\mathbf{L C}(\boldsymbol{\%})$ & $\mathbf{E E ~}(\boldsymbol{\%})$ \\
\hline A1E1 & $2: 1$ & 2 & $36,03 \pm 0.53^{\mathrm{b}}$ & $6,69 \pm 0.35^{\mathrm{a}}$ & $74,87 \pm 1,75^{\mathrm{c}}$ \\
A1E2 & $2: 1$ & 3 & $46,43 \pm 2.37^{\mathrm{a}}$ & $6,58 \pm 0.15^{\mathrm{a}}$ & $75,96 \pm 0,52^{\mathrm{c}}$ \\
A2E1 & $1: 1$ & 2 & $40,59 \pm 3.34^{\mathrm{a}}$ & $5,85 \pm 0.19^{\mathrm{b}}$ & $79,99 \pm 1,47^{\mathrm{b}}$ \\
A2E2 & $1: 1$ & 3 & $47,92 \pm 0.29^{\mathrm{b}}$ & $5,73 \pm 0.51^{\mathrm{b}}$ & $80,26 \pm 1,92^{\mathrm{b}}$ \\
A3E1 & $1: 2$ & 2 & $38,19 \pm 0.22^{\mathrm{b}}$ & $5,43 \pm 0.55^{\mathrm{b}}$ & $91,21 \pm 0,76^{\mathrm{a}}$ \\
A3E2 & $1: 2$ & 3 & $45,18 \pm 0.56^{\mathrm{b}}$ & $5,37 \pm 0.31^{\mathrm{b}}$ & $92,20 \pm 0,51^{\mathrm{a}}$ \\
\hline
\end{tabular}

Nilai dari masing-masing parameter yang diikuti oleh huruf yang sama dalam kolom menunjukkan perbedaan tidak nyata pada uji Least Significant Differences LSD (p>0.05). M: Minyak Atsiri, P: Penyalut, CA: Crosslinking Agent, Y: Yield, LC: Loading Capacity, EE: Efisiensi Enkapsulasi. 
Beberapa faktor yang mempengaruhi nilai yield adalah bahan pembentuk mikrokapsul dan jumlah minyak atsiri yang ditambahkan pada emulsi. Jumlah bahan pembentuk mikrokapsul dalam basis kering pada formulasi dengan crosslinking agent 3\% lebih tinggi dibandingkan dengan crosslinking agent $2 \%$. Sehingga, volume emulsi yang dihasilkan pada proses koaservasi kompleks juga lebih tinggi. Hal ini menyebabkan pada proses pengeringan menghasilkan mikrokapsul bubuk dengan jumlah yang lebih tinggi.

Formulasi dengan jumlah minyak atsiri yang lebih tinggi pada umumnya menghasilkan yield yang lebih rendah. Hal ini dikarenakan semakin tingginya konsentrasi atau jumlah minyak atsiri yang ditambahkan maka akan mengurangi kapasitas dari kemampuan polimer dalam mengenkapsulasi seluruh minyak atsiri yang terdapat pada matriks, sehingga jumlah minyak atsiri yang tidak terenkapsulasi atau surface oil akan meningkat dan mengurangi jumlah mikrokapsul pada collector alat spray dryer (Burhan et al., 2019). Yield juga dipengaruhi oleh kondisi hilangnya produk yang dimulai dari proses pembuatan emulsi mikrokapsul dan adanya produk yang masih menempel pada collector saat proses pengeringan menggunakan spray drying. Komponen penyusun minyak atsiri dan penyalut yang terdapat pada emulsi yang digunakan pada saat pengeringan menggunakan spray drying juga akan mempengaruhi yield yang dihasilkan (Otalora et al., 2015). Hasil analisis terhadap nilai yield dapat dilihat pada Gambar 2.

Pada penelitian ini yield yang dihasilkan lebih tinggi dibandingkan Otalora et al. (2015) yang menggunakan proses homogenisasi dan teknik pengeringan spray drying dalam enkapsulasi betalain dengan penyalut maltodekstrin dengan yield 16,4$25,4 \%$. Hal ini karena adanya penambahan crosslinking agent ke dalam emulsi pada proses koaservasi kompleks, sehingga matriks yang terbentuk lebih tahan terhadap suhu dan mengurangi jumlah senyawa aktif yang hilang selama proses pengeringan spray drying. Penelitian Adamiec dan Kalemba (2006) melakukan enkapsulasi minyak atsiri elemi dan minyak atsiri peppermint dengan penyalut maltodekstrin menggunakan proses emulsifikasi dan teknik pengeringan spray drying mendapatkan hasil yield yang nilainya mendekati nilai pada penelitian ini yaitu untuk minyak atsiri elemi $29,10-41,40 \%$ dan untuk minyak atsiri peppermint $57,20-70,60 \%$. Hasil penelitian Burhan et al. (2019) mendapatkan yield $42,10-63,50 \%$ pada enkapsulasi minyak atsiri lavender menggunakan penyalut maltodekstrin dan gum arab dengan proses emulsifikasi dan teknik pengeringan spray drying.

\section{Loading Capacity Mikrokapsul}

Nilai loading capacity yang didapatkan menggambarkan jumlah minyak yang mampu dienkapsulasi pada jumlah mikrokapsul tertentu yang didapat setelah proses pengeringan. Perbandingan minyak atsiri dan penyalut pada proses enkapsulasi memberikan pengaruh nyata terhadap nilai loading capacity yang dihasilkan, hal ini ditunjukkan oleh hasil analisis ragam dengan nilai signifikansi yang lebih kecil dari 5\% $(\alpha=0,05)$, sebaliknya konsentrasi crosslinking agent tidak memberikan pengaruh yang nyata terhadap nilai loading capacity.

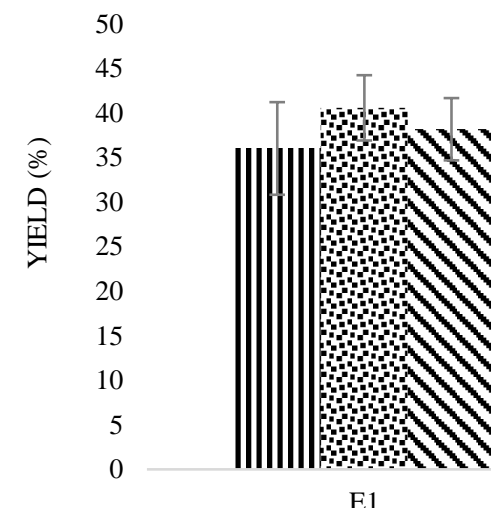

Ket:

A1: Minyak atsiri: Penyalut 2:1

A2: Minyak atsiri: Penyalut 1:1

A3: Minyak atsiri: Penyalut 1:2

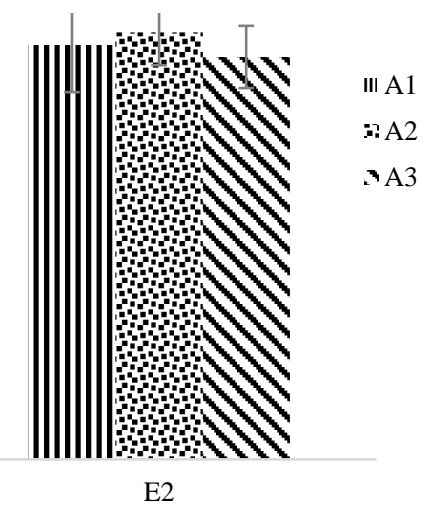

E1: Crosslinking agent $2 \%$

E2: Crosslinking agent $3 \%$

Gambar 2. Nilai Yield Mikrokapsul 
Berdasarkan perhitungan yang telah dilakukan, loading capacity yang didapatkan dari enam formulasi pada penelitian ini adalah pada rentang 5,37-6,69\%. Tidak ada perbedaan hasil yang signifikan antara penggunaan crosslinking agent pada konsentrasi 2\% dan 3\%. Hal ini disebabkan karena crosslinking agent dalam jumlah tertentu memiliki batas maksimum sebagai fungsinya dalam menambah kekuatan ikatan silang dalam suatu matriks, sehingga antara penggunaan pada konsentrasi yang berbeda antara $2 \%$ dan $3 \%$ pada emulsi tidak memberikan pengaruh yang berbeda terhadap produk mikrokapsul yang dihasilkan. Menurut Kokini (2002), crosslinking agent memberikan sifat kaku pada matriks yang terbentuk dari dua polimer, namun kekuatan dari crosslinking agent juga dipengaruhi oleh kondisi $\mathrm{pH}$, waktu dan suhu emulsi

Penelitian Kanha et al. (2020) menyatakan bahwa proses pengeringan menggunakan spray drying juga mempengaruhi nilai loading capacity. Penggunaan panas pada proses pengeringan dengan spray drying ini menyebabkan hilangnya komponen yang bersifat volatil selama proses pembentukan bubuk mikrokapsul. Berdasarkan hasil penelitian Kanha et al. (2020) nilai loading capacity mikrokapsul dengan proses pengeringan dengan spray drying adalah 18,3-28,7\%, sedangkan pada proses pengeringan dengan freeze drying adalah 31,9$34,5 \%$. Namun, pada efisiensi proses dari segi waktu dan biaya tetap spray drying lebih unggul karena tidak memerlukan waktu pengeringan yang lama dibandingkan freeze drying.

Loading capacity memiliki hubungan yang erat dengan jumlah minyak atsiri yang ditambahkan pada formulasi, semakin banyak jumlah minyak maka semakin tinggi nilai loading capacity yang didapatkan. Penelitian Shetta et al. (2018) memperoleh nilai loading capacity dengan rentang nilai $8,15-22,2 \%$ untuk minyak atsiri peppermint dan 2,2-23,1\% untuk minyak atsiri teh hijau yang menggunakan kitosan sebagai penyalut. Nilai tersebut masih mendekati kisaran nilai loading capacity yang diperoleh dalam penelitian ini. Benavides et al. (2016) memperoleh nilai loading capacity yang lebih tinggi ketika melakukan enkapsulasi minyak atsiri thyme menggunakan penyalut sodium alginat yaitu sebesar $30-56,4 \%$. Senyawa aktif pada setiap minyak atsiri memiliki ukuran molekuler yang berbeda, sehingga akan mempengaruhi kemampuan polimer dan crosslinking agent dalam membentuk matriks pada saat proses enkapsulasi. Hal ini yang menyebabkan pada setiap jenis minyak atsiri dan proses enkapsulasi yang digunakan menghasilkan nilai loading capacity yang berbeda. Hasil analisis terhadap nilai loading capacity dapat dilihat pada Gambar 3.

\section{Efisiensi Enkapsulasi Mikrokapsul}

Efisiensi enkapsulasi merupakan perbandingan antara total minyak yang terenkapsulasi dengan total minyak yang terdapat pada mikrokapsul. Formulasi dengan nilai efisiensi enkapsulasi tertinggi adalah formulasi A3E2. Hasil analisis ragam efisiensi enkapsulasi ini menunjukkan nilai signifikansi yang lebih kecil dari dari $5 \%(\alpha=0,05)$ untuk perbandingan minyak atsiri dan penyalut, sedangkan nilai signifikansi yang lebih besar dari $5 \%(\alpha=0,05)$ untuk konsentrasi crosslinking agent. Hasil analisis efisiensi enkapsulasi ini menunjukkan bahwa perbandingan minyak atsiri dan penyalut pada proses enkapsulasi minyak atsiri memberikan pengaruh nyata terhadap nilai efisiensi enkapsulasi, sebaliknya konsentrasi crosslinking agent tidak memberikan pengaruh nyata terhadap nilai efisiensi enkapsulasi.

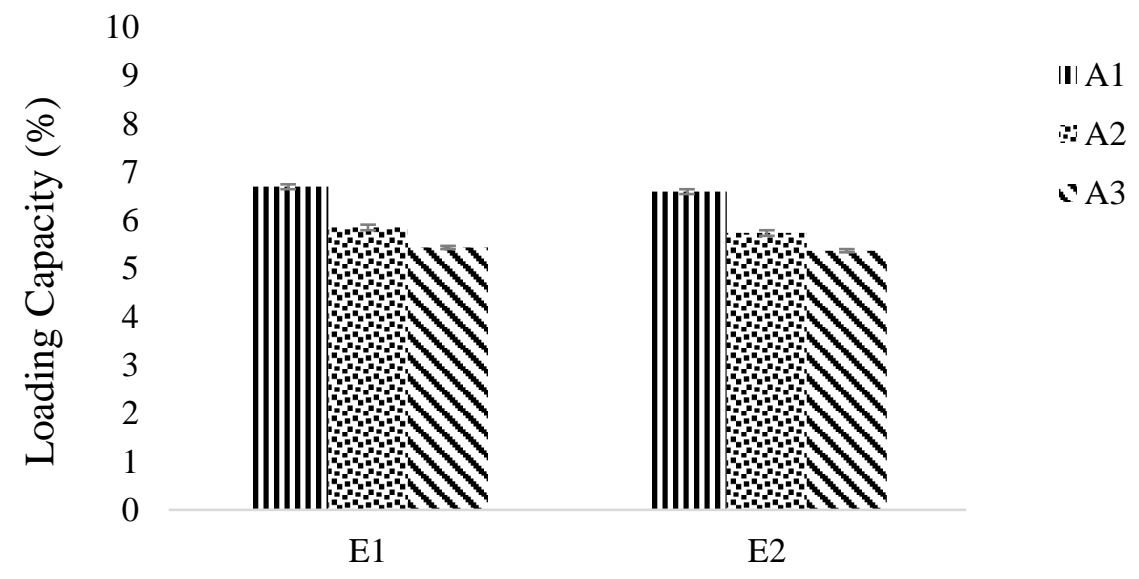

A1: Minyak atsiri: Penyalut 2:1

E1: Crosslinking agent $2 \%$

A2: Minyak atsiri: Penyalut $1: 1$

E2: Crosslinking agent 3\%

A3: Minyak atsiri: Penyalut 1:2

Gambar 3. Nilai Loading Capacity Mikrokapsul 
Formulasi A3E2 merupakan formulasi dengan perbandingan minyak atsiri dan penyalut adalah $1: 2$ dengan konsentrasi crosslinking agent sebesar 3\%. Penyalut dengan jumlah dua kali minyak atsiri lebih efektif dalam proses enkapsulasi karena peluang untuk tidak terenkapsulasinya minyak atau yang disebut dengan surface oil di dalam matriks lebih kecil. Surface oil merupakan jumlah minyak yang terdapat di permukaan mikrokapsul yang tidak terenkapsulasi. Untuk mendapatkan jumlah minyak yang terenkapsulasi adalah dengan mengetahui jumlah total minyak yang terdapat di mikrokapsul dan dikurangi dengan surface oil. Nilai surface oil yang rendah menunjukkan tingginya jumlah minyak yang terenkapsulasi. Efisiensi enkapsulasi juga dipengaruhi oleh konsentrasi crosslinking agent yang digunakan, tetapi pada penelitian ini tidak ada perbedaan nilai efisiensi enkapsulasi yang signifikan antara penggunaan crosslinking agent $2 \%$ dan $3 \%$.

Minyak atsiri yang digunakan sebelum proses emulsifikasi diperkirakan akan menguap sehingga jumlahnya berkurang. Untuk itu pembuatan emulsi yang dilakukan dalam proses enkapsulasi minyak atsiri dengan teknik koaservasi kompleks ini merupakan proses modifikasi kondisi menggunakan crosslinking agent agar loss minyak atsiri menjadi surface oil menurun. Nilai efisiensi enkapsulasi dalam penelitian ini juga menurun dengan adanya peningkatan jumlah minyak atsiri yang digunakan untuk setiap formulasi. Efisiensi enkapsulasi berbanding terbalik dengan nilai loading capacity. Efisiensi enkapsulasi merupakan salah satu parameter penting yang harus dikontrol dan dimaksimalkan pada proses enkapsulasi (Liu, 2009). Hasil analisis terhadap nilai efisiensi enkapsulasi dapat dilihat pada Gambar 4.

\section{Formulasi Terbaik Mikrokapsul}

Formulasi terbaik pada penelitian ini dihitung berdasarkan metode indeks efektivitas (DeGarmo et al., 1984). Metode indeks efektivitas dilakukan dengan pemberian bobot pada masing-masing parameter berdasarkan kepentingan. Bobot nilai tiga parameter berdasarkan kepentingan dalam penelitian ini adalah 1 untuk efisiensi enkapsulasi, 0,9 untuk loading capacity dan 0,8 untuk yield. Perhitungan nilai efektivitas didapatkan dari nilai selisih antara nilai perlakuan tertinggi dengan nilai perlakuan terendah pada masing-masing formulasi. Berdasarkan perhitungan bobot nilai dan nilai efektivitas maka didapatkan nilai untuk seluruh formulasi yang dapat dilihat pada Tabel 2.

Formulasi dengan total nilai produk tertinggi yaitu 0,60 ditunjukkan oleh formulasi A3E2 dengan perbandingan minyak atsiri dan penyalut adalah 1:2 dan konsentrasi crosslinking agent yang digunakan adalah 3\%. Hasil ini menunjukkan bahwa perbandingan pada formulasi A3E2 menghasilkan produk enkapsulasi dengan nilai produktifitas yang lebih tinggi dibandingkan dengan formulasi lainnya. Nilai produktivitas ini menggambarkan produk sediaan aromaterapi yang memiliki nilai yield, loading capacity dan efisiensi enkapsulasi terbaik, dimana secara kuantitas dan kualitas lebih tinggi.

\section{Ukuran Mikrokapsul}

Hasil pengukuran partikel formulasi A3E2 menunjukkan rata-rata $0,1475 \mu \mathrm{m}$ dengan polydispersity index (PdI) 0,410. Polydispersity Index (PdI) adalah suatu pengukuran terhadap keseragaman suatu partikel yang menggambarkan distribusi ukuran (Taurina et al. 2017). Nilai yang ditunjukkan oleh indeks polidispersitas ini ada pada rentang 0-1. Nilai indeks polidispersitas yang semakin kecil dan mendekati 0 menunjukkan bahwa partikel tersebut semakin homogen, sebaliknya semakin besar dan mendekati 1 menunjukkan bahwa partikel tersebut heterogen.

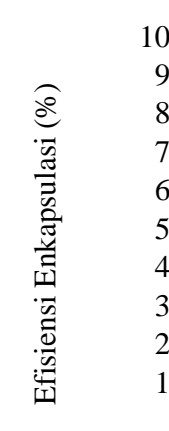

Ket:

A1: Minyak atsiri: Penyalut 2:1

A2: Minyak atsiri: Penyalut $1: 1$

A3: Minyak atsiri: Penyalut 1:2
(I) A1

$\therefore \mathrm{A} 2$

: $\mathrm{A} 3$

\section{Gambar 4. Nilai Efisiensi Enkapsulasi Mikrokapsul}


Tabel 2. Hasil analisis perlakuan terbaik dengan metode indeks efektivitas

\begin{tabular}{ccccccc}
\hline Formulasi & M:P & CA $(\% \mathrm{~b} / \mathrm{v})$ & Y & LC & EE & Total Nilai Produk \\
\hline A1E1 & $2: 1$ & 2 & 0,00 & 0,33 & 0,00 & 0,33 \\
A1E2 & $2: 1$ & 3 & 0,26 & 0,30 & 0,02 & 0,59 \\
A2E1 & $1: 1$ & 2 & 0,12 & 0,12 & 0,11 & 0,34 \\
A2E2 & $1: 1$ & 3 & 0,30 & 0,09 & 0,12 & 0,51 \\
A3E1 & $1: 2$ & 2 & 0,05 & 0,02 & 0,35 & 0,42 \\
A3E2 & $1: 2$ & 3 & 0,23 & 0,00 & 0,37 & $0,60^{*}$ \\
\hline
\end{tabular}

*Bobot nilai produk tertinggi merupakan formulasi dengan perlakuan terbaik

Penelitian Benavides et al. (2016) menyatakan bahwa nilai indeks polidispersitas yang baik adalah dengan nilai dibawah 0,5 dan akan menghasilkan mikrokapsul yang homogen. Hasil ini menunjukkan bahwa partikel mikrokapsul minyak atsiri terenkapsulasi pada formulasi A3E2 sudah seragam, stabil dan memiliki nilai aglomerasi yang rendah. Pengukuran penyebaran partikel formulasi terbaik berdasarkan intensitas menunjukkan pola dimana semakin sedikit puncak yang terbentuk pada kurva maka sampel yang diukur semakin homogen dan stabil, sebaliknya semakin banyak puncak yang terbentuk pada kurva maka sampel yang diukur semakin beragam dan heterogen. Kurva pengukuran mikrokapsul berdasarkan intensitas penyebaran dapat dilihat pada Gambar 5.

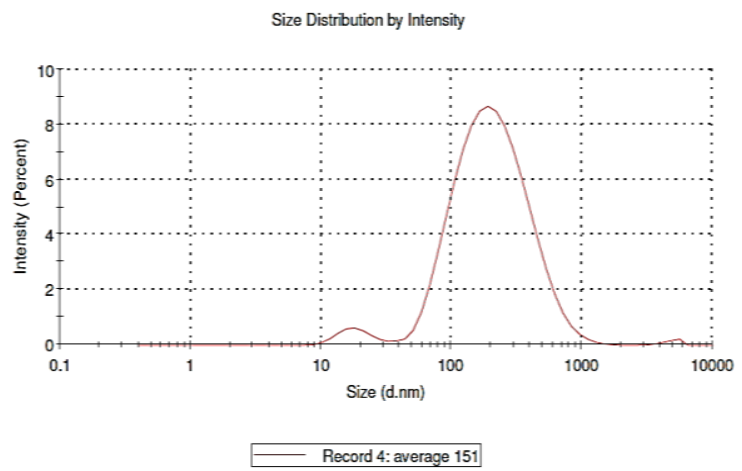

Gambar 5. Kurva distribusi ukuran partikel formulasi A3E2 berdasarkan intenstias

\section{KESIMPULAN DAN SARAN}

\section{Kesimpulan}

Perbandingan antara minyak atsiri, penyalut dan crosslinking agent berpengaruh terhadap karakteristik mikrokapsul yang dihasilkan. Formulasi A3E2 dengan perbandingan minyak atsiri dan penyalut yaitu 1:2 dan crosslinking agent 3\% merupakan formulasi terbaik karena memiliki karakteristik dengan nilai paling optimum yaitu yield $45,18 \%$, loading capacity $5,37 \%$ dan efisiensi enkapsulasi 92,20\%. Ukuran mikrokapsul yang dihasilkan adalah $0,1475 \mu \mathrm{m}$ dengan indeks polidispersitas (PdI) 0,410.

\section{Saran}

Penelitian lebih lanjut diharapkan dapat menambah variasi konsentrasi crosslinking agent yang digunakan agar terlihat pengaruh perbedaan secara nyata terhadap parameter yield, loading capacity dan efisiensi enkapsulasi. Perlu dilakukan pertimbangan lebih lanjut untuk pemilihan metode pengeringan yang akan digunakan, karena suhu tinggi pada spray drying menyebabkan kehilangan minyak atsiri yang cukup tinggi.

\section{DAFTAR PUSTAKA}

Adamiec J, Kalemba D. 2006. Analysis of microencapsulation ability of essential oils during spray drying. International Journal Drying Technology. 24 (9): 1127-1132.

Ali B, Alwabel NA, Shams S, Ahamad A, Khan SA, Anwar F. 2015. Essential oils used in aromatherapy: A Systemic Review. Asian Pacific Journal Tropical Biomedicine. 1-11.

Ali MM, Yusuf MA, Abdalaziz MN. 2017. GC-MS Analysis and antimicrobial screening of essential oil from lemongrass (Cymbopogon citratus). International Journal Pharmacy and Chemistry 3(6): 72-76.

Benavides S, Cortes P, Parada J, Franco W. 2016. Development of alginate microspheres containing thyme essential oil using ionic gelation. International Journal Food Chemistry. 204 : 77-83.

Bezerra FM, Carmona OG, Carmona CG, Lis MJ, Moraes FF. 2016. Controlled release of the essential oil of citronella microencapsulated using cotton and polyester matrix. International Journal Cellulose. 23: 14591470.

Botrel DA, Fernandes RVB, Borges SV. 2015. Microencapsulation of Essential Oils Using Spray Drying Technology. Dalam buku "Microencapsulation and Microspheres". Sagis LMC (Editor). E-book Series. doi: https://doi.org/10.1016/C2013-0-18624-2.

Burhan AM, Hamid SMA, Soliman ME, Sammour OA. 2019. Optimisation of the microencapsulation of lavender oil by spray drying. International Journal Microencapsulation. 36 (3): 250-266.

DeGarmo EP, Sullivan WG, Canada JR. 1984. Engineering Economy, 264-266.

Gupta S, Khan S, Muzafar M, Kushwaha M, Yadav AK, Gupta AP. 2016. Encapsulation: Entrapping Essential Oil; Flavors or Aromas in 
Food. Dalam Buku "Encapsulations". Grumezescu A (Authors). E-Book Series.

Harianingsih, Wulandari R, Harliyanto C, Andiani CN. 2017. Identifikasi GC-MS Ekstrak Minyak Atsiri dari Sereh Wangi (Cymbopogon winterianus) Using Metanol Solvent. Balai Pengkajian Teknologi Pertanian Aceh. Techno P. 18 (1): 023-027.

Kamala N. 2010. Mikroenkapsulasi Vitamin A Palmitat dengan Menggunakan Gelatin-Akasia Secara Koaservasi Kompleks. [Skripsi] Universitas Indonesia.

Kanha N, Regenstein JM, Surawang S, Pitchakarn P, Laokuldilok T. 2020. Properties and kinetics of the in vitro release of anthocyanin-rich microcapsules produced through spray and freeze-drying complex coacervated double emulsions. Journal Food Chemistry. 340 (11 pages).

Kokini JL. 2002. Understanding the mechanism of cross-linking agents (POCl3, STMP, and EPI) through swelling behavior and pasting properties of cross-linking waxy maize starches 1. American Association Cereal Chemistry. 79 (1): 102-107.

Liu S. 2009. Encapsulation of Flax Oil by Complex Coacervation. [Tesis] University of Saskatchewan.

Manaf MA, Subuki I, Jai J, Raslan R, Mustapa AN. 2018. Encapsulation of volatile citronella essential oil by coacervation: efficiency and release study. IOP Conference Series: Material Sciences and Engineering. 358 (2018) 012072.

Otalora MC, Carriazo JG, Iturriaga L, Nazareno MA, Osorio C. 2015. Microencapsulation of betalains obtained from cactus fruit (Opuntia ficus-indica) by spray drying using cactus cladode mucilage and maltodextrin as encapsulating agents. Journal Food Chemistry. 187: 174-188.

Shetta A, Kegere J, dan Mamdouh W. 2018. Comparative study of encapsulated peppermint and green tea essential oils in chitosan nanoparticles: encapsulation, thermal stability, in-vitro release, antioxidant and antibacterial activities. International Journal Biological Macromolecules. 126:731-742.

Singh P, Andola H, Rawat MSM, Pant GJ, Jangwan JS. 2015. GC-MS Analysis of essential oil from lavandula angustifolia cultivated in garhwal himalaya. International Journal The Natural Products. 5 : 268-272.

Taurina W, Sari R, Hafinur UC, Wahdaningsih S, Isnindar. 2017. optimasi kecepatan dan lama pengadukan terhadap ukuran nanopartikel kitosan-ekstrak etanol $70 \%$ kulit jeruk siam (Citrus nobilis L.var Microcarpa). Traditional Medicine Journal. 22(1): 16-20.

Xiao Z, Liu W, Zhu G, Zhou R, Niu Y. 2013. Production and characterization of multinuclear microcapsules encapsulating lavender oil by complex coacervation. Flavor and Fragrance Journal. 29: 166-172.

Yunika C. 2017. Pengaruh komposisi bahan penyalut dan suhu spray drying terhadap karakteristik nanoenkapsulat minyak kayu manis (Cinnamomum burmanii). [Skripsi] Institut Pertanian Bogor. 